ISSN 1392-3196 / e-ISSN 2335-8947

Zemdirbyste-Agriculture, vol. 101, No. 3 (2014), p. 279-284

DOI $10.13080 / \mathrm{z}-\mathrm{a} .2014 .101 .036$

\title{
The effect of Cry1 AB insecticidal protein on the incidence of entomopathogenic fungi infecting aphids on $B t$ maize
}

\author{
Michał HUREJ ${ }^{1}$, Ryszard MIĘTKIEWSKI ${ }^{2}$, Jacek Piotr TWARDOWSKI ${ }^{1}$ \\ ${ }^{1}$ Wrocław University of Environmental and Life Sciences \\ Grunwaldzki 24A, 50-363 Wroclaw, Poland \\ E-mail: michal.hurej@up.wroc.pl \\ ${ }^{2}$ University of Podlasie \\ Prusa 14, 08-110 Siedlce, Poland
}

\begin{abstract}
There are substantial discrepancies in risk assessments of transgenic maize in Europe. The aim of the study was to determine the quantitative changes in the proportion of fungi-infected aphids and possible differences in the species composition of entomopathogenic fungi on conventional and genetically modified maize, expressing Cry $1 \mathrm{Ab}$ protein from Bacillus thuringiensis (Bt). The experiments were performed in Lower Silesia, Poland, in 2008-2010. Three cultivars were used, i.e. DKC 3421 YG (Bt), isogenic non- $B t$ DKC 3420, and the conventional 'Bosman' as a reference. Aphids infected with fungi were counted in situ on 18 plants per plot every two weeks through each of the growing seasons. Additionally, twice a year dead aphids were also collected ( 60 aphids per treatment) and used for fungi identification. Cry $1 \mathrm{Ab}$ insecticidal protein had no effect on the incidence of entomopathogenic fungi infecting aphids on $B t$ maize. The number of fungi-infected aphids and their time of occurrence were similar on the three compared cultivars. The same three or four species of entomopathogenic fungi-infected aphids were found in each treatment. Predominating in all the treatments were Pandora neoaphidis, Entomophthora planchoniana and Conidiobolus thromboides.
\end{abstract}

Key words: Cry1 Ab protein, genetically modified crop, mycosed aphids, pest, transgenic maize.

\section{Introduction}

Bacillus thuringensis $(B t)$ maize expressing the insecticidal protein CrylAb very effectively controls the primary target pest, the European corn borer (Ostrinia nubilalis Hübner) (Lepidoptera: Crambidae) (Bereś, 2010). In plant protection, this prevents from causing damage throughout the season and economic loss, thus eliminating the need for extensive monitoring and application of corn borer insecticides. Aphids (Hemiptera: Aphididae) are another group feeding on maize. However, they occur irregularly and are not a problem every season (Faria et al., 2007). Adults and nymphs suck sap and produce honeydew. High densities can cause plants to turn yellow and appear unproductive. Yield loss may occur on water-stressed plants (Honek, 1994). Up to now, four aphid species have been identified on maize in Poland, i.e. Rhopalosiphum padi (Linnaeus, 1758), Metopolophium dirhodum (Walker, 1849), Sitobion avenae (Fabricius, 1775), and Rhopalosiphum maidis (Fitch, 1856) (Pieńkosz et al., 2005). A similar finding prevails in most European countries, sometimes with the changes of dominant species (Honek, 1994).

With the rapid increase in the commercial use of genetically modified (GM) plants, there is an increasing demand for information on their possible impact on nontarget organisms. Of particular interest are the natural enemies of pests and antagonistic microorganisms, such as entomopathogenic fungi, which play an important role in pest regulation. Fungi can effectively reduce aphids (Ekesi et al., 2005). On maize, the infection of $M$. dirhodum and $R$. padi by pathogenic fungi reached $68.5 \%$ and $82.1 \%$, respectively (Krawczyk et al., 2006). According to the same authors, apterae females and larvae were infected in the greatest number. The mummified aphids were mostly infected by Pandora neoaphidis (Remaudiere et Hennebert) Humber.

The Bacillus thuringensis delta-endotoxinprotein Cry1 Ab from GM maize is considered very selective in its action and should not affect non-target arthropods associated with maize. The fact that the bacterial protein is not transported in the plant phloem leaves aphids unaffected by its direct action. Many studies have shown that $B t$ maize has no effect on $R$. padi, M. dirhodum or $S$. avenae development (Dutton et al., 2002; Habuštova et al., 2014). Despite this, the newest data from the enzyme linked immunosorbent assay (ELISA) tests referring to $\mathrm{Cry} 3 \mathrm{Bb}$ toxin produced to control western corn rootworm (Diabrotica virgifera virgifera LeConte) on maize indicate possibilities of $B t$ protein flow from the plant to predators via the aphids (Stephens et al., 2012). According to these authors, ladybird Harmonia axyridis 
feeding upon Rhopalosiphum maidis on Cry3Bb plants in the field may experience greater mortality and shorter life spans. Burgio et al. (2011) highlighted the potential for Cry1Ac endotoxin uptake by aphids feeding on transgenic oilseed rape plants. In the study by Lumbierres et al. (2004), it was found that young nymphs of $R$. padi were colonizing $B t$ transgenic maize at a higher density, especially when the plants started growing in a commercial field. Together these data suggest that non-target organisms can be affected indirectly by $B t$ maize via a secondary pest, maize leaf aphids. To date, no studies on the indirect impact of GM maize plants with Cry1Ab protein on entomopathogenic fungi-infected plant dwelling aphids have been performed, and, in the available literature, there is a deficiency of data concerning this problem.

The aim of the present study was to determine the quantitative changes in the proportion of fungiinfected aphids, and possible differences in the species composition of entomopathogenic fungi that kill these insects on conventional and Bt maize grown for grain.

\section{Materials and methods}

The experiments were performed in Budziszów $\left(51^{\circ} 06^{\prime} \mathrm{N}, 17^{\circ} 02^{\prime} \mathrm{E}\right)$, near Wrocław, Lower Silesia, Poland, in 2008-2010. Three cultivars of maize were cultivated: 1) genetically modified (GM) plants MON 810, expressing Cry1Ab protein from Bacillus thuringensis (Bt) cv. DKC 3421 Yield Gard $^{\circledR}$ ("Monsanto", USA), 2) an isogenic non- $B t$ cv. DKC 3420 ("Monsanto"), and 3) a conventional, reference cv. 'Bosman' (national cultivar 'Nasiona Kobierzyce'). All the three cultivars are described with FAO numbers 250-260. The field experiment was set up in complete randomized blocks with four replicates. The area of each experimental plot was $1.600 \mathrm{~m}^{2}(40 \times 40 \mathrm{~m})$. An alley distance of $4.5 \mathrm{~m}$ was used between plots. The experiments were conducted on the same plots for three consecutive years; hence we could expect the growing amount of $B t$ endotoxin. No insecticides were used in this experiment. All the agrotechnologies applied in the maize field, including fertilizers, were identical on the entire area of the experiment.

The fungi-infected aphids were counted in situ on 18 plants per plot (72 per treatment), every two weeks from the beginning to the end of the maize growing season. If maize plants were found infested by aphids, the aphid colonies were visually examined to find individuals with external symptoms of fungal infection. Plants were chosen randomly at three points on the diagonal of each plot (six plants at each point). Additionally, twice a growing season the fungi-infected aphids were also collected for fungi identification. The first time was always in June, and the second one - if insects were available - at the beginning of October. Fifteen dead aphids were collected at random from each plot (one aphid from one plant diagonally across the plot), 60 aphids per treatment. Microscope slides of dead aphids were prepared. The taxonomic keys by Keller (1987, 1991) and Humber (1997) were used for the parasitic fungi identification.

Data were analyzed by $A N O V A$ in the repeated measures procedure. In order to recognize the differences between the maize cultivars with respect to the number of aphids as well as fungi-infected aphids the collected data were analysed using Tukey's honest significant difference (post-hoc) test at a 5\% level of significance. The data were normally distributed. To avoid the influence of seasonal trends statistical analysis was also carried out separately by one-way ANOVA $(P<0.05)$ for each data set.

\section{Results}

Number and quantity changes of fungiinfected aphids. In the three years of the study, in total 10461 aphids infected by entomopathogenic fungi were recorded on all the observed maize cultivars (Table 1). Clearly more fungi-infected aphids were found in 2008 (6929) compared to 2009 (2707) or to 2010 (825). Almost the same number of fungi-infected insects occurred on both $B t$ maize (4059) and the isogenic non-Bt cultivar (3866), whereas the incidence of infected aphids was somewhat lower on the conventional reference $\mathrm{cv}$. 'Bosman' (2536).

Table 1. Total number of fungi-infected aphids recorded from maize plants in 2008-2010

\begin{tabular}{ccccc}
\hline Year & DKC 3421 YG & DKC 3420 & 'Bosman' & Total \\
\hline 2008 & 2776 & 2792 & 1361 & 6929 \\
2009 & 945 & 854 & 908 & 2707 \\
2010 & 338 & 220 & 267 & 825 \\
\hline Total & 4059 & 3866 & 2536 & 10461 \\
\hline
\end{tabular}

In 2008, aphids infected by entomopathogenic fungi were found only on the three observation dates, i.e. at the end of June, in mid-July, and at the end of July (Fig. 1). In the first observation, 356 dead aphids were recorded on the reference cv. 'Bosman', 716 insects on cv. DKC 3420, and 822 individuals on the $B t \mathrm{cv}$. DKC 3421 Yield Gard. The maximum number of mycosed aphids occurred during the second observation. Again, the lowest number of infected insects was observed on the cv. 'Bosman' (753). On the Bt cultivar 1261 aphids were mycosed, while on the isogenic non- $B t$ cultivar 1222 aphids. At maximum aphids' infection the maize plants were at the BBCH stages 59-61. In the third count, 252 aphids were found infected on the conventional cultivar, 688 on $B t$ maize, and 854 on the isogenic non$B t$ cultivar. No statistically significant differences were found between the number of fungi-infected aphids noted on the three cultivars $(F=0.9182, \mathrm{df}=2, p=0.4127)$.

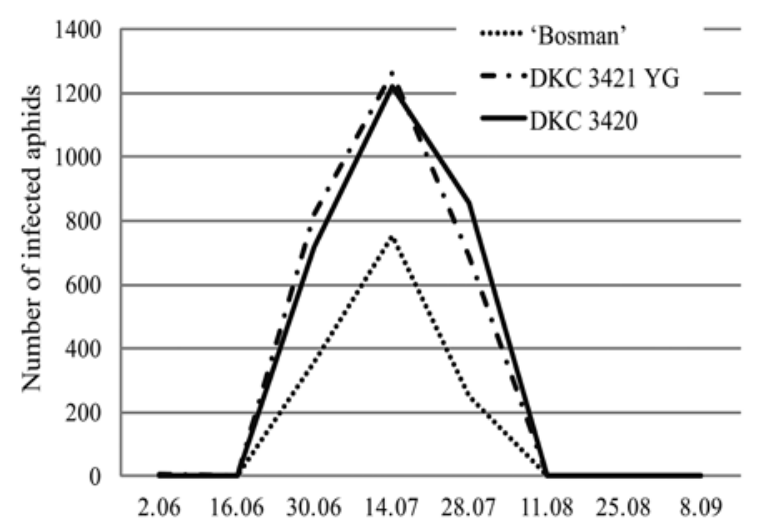

Figure 1. Number of aphids infected by entomopathogenic fungi recorded from maize plants in 2008 
In 2009, fungi-infected aphids were recorded on maize from the end of June to mid-September (Fig. 2). The maximum number of mycoses was found on all three cultivars before the $10^{\text {th }}$ day of July, when plants were at the $\mathrm{BBCH}$ stage 53 . At the maximum 613 dead insects were collected on the cv. 'Bosman', 653 on the cv. DKC 3420 , and 657 on the cv. DKC 3421 YG. The fungiinfected aphids were still numerous in the second half of July and at the beginning of August. Later, i.e. in the second half of August and in the first half of September, only single dead individuals occurred on the maize. As in the previous year, no significant differences were found between aphids infected with fungi on analysed cultivars $(F=0.005642, \mathrm{df}=2, p=0.9943)$.

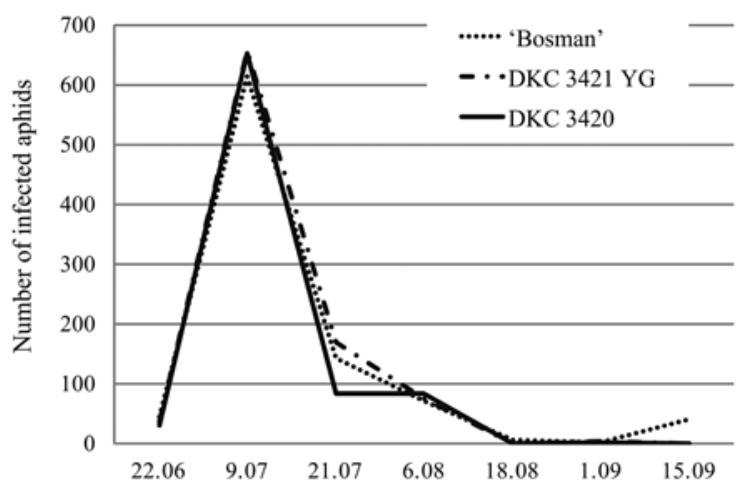

Figure 2. Number of aphids infected by entomopathogenic fungi recorded from maize plants in 2009

In 2010, mycosed aphids were recorded on maize plants from the last ten days of June to the beginning of September (Fig. 3). On each cultivar, the highest number of infected insects occurred, as in 2009 , before the $10^{\text {th }}$ day of July, on plants at BBCH stage 53 . At the time of the maximum incidence of infections, almost similar numbers of mycoses were found on the conventional ('Bosman') cultivar (90), on the cv. DKC 3421 YG (93), and on the isogenic non-Bt maize (105). Decreasing numbers of fungi-infected aphids were observed later in the season. The last, single individuals were found in the first days of September. Also, in that last year no significant differences were found between number of fungi-infected aphids among the three maize cultivars $(F=0.02440, \mathrm{df}=2, p=0.9759)$.

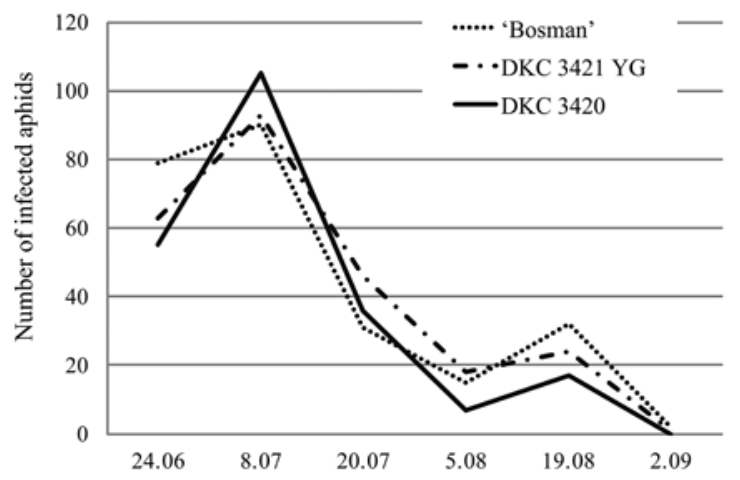

Figure 3. Number of aphids infected by entomopathogenic fungi recorded from maize plants in 2010

Spectrum of fungal species. In 2008, two species of entomopathogenic fungi were identified from the dead aphid mummy material collected in July on cvs DKC 3421 YG and 'Bosman' and three species on cv. DKC 3420 (Table 2). The most numerous species on all the three cultivars was $P$. neoaphidis. This species infected from $66.1 \%$ (cv. DKC 3420) to $70.8 \%$ (cv. 'Bosman') of all mycosed aphids. Less abundant was Entomophthora planchoniana. Mortality caused by this latter fungus ranged from $26.8 \%$ (cv. DKC 3420 ) to $33.3 \%$ (cv. DKC 3421 YG). Conidiobolus thromboides was identified only in individual dead insects collected from cv. DKC 3420 plants. As shown in Table 2, not all collected (60 individuals) aphids were infected by entomopathogenic fungi, but the factors responsible for the other individuals' mortality were not found. No aphids infected by entomopathogenic fungi were observed on maize in October 2008.

Table 2. Species composition of entomopathogenic fungi in 2008 (July)

\begin{tabular}{lcccccccc}
\hline \multicolumn{1}{c}{ Species } & \multicolumn{2}{c}{ DKC3421 YG } & \multicolumn{2}{c}{ DKC 3420 } & \multicolumn{2}{c}{ 'Bosman' } & \multicolumn{2}{c}{ Total } \\
\cline { 2 - 9 } & $\mathrm{n}$ & $\%$ & $\mathrm{n}$ & $\%$ & $\mathrm{n}$ & $\%$ & $\mathrm{n}$ & $\%$ \\
\hline Pandora neoaphidis (Remaudiere et Hennebert) Humber & 36 & 66.7 & 37 & 66.1 & 34 & 70.8 & 107 & 67.7 \\
Entomophthora planchoniana Cornu & 18 & 33.3 & 15 & 26.8 & 14 & 29.2 & 47 & 29.7 \\
Conidiobolus thromboides Dreschler & 0 & 0 & 4 & 7.1 & 0 & 0 & 4 & 2.6 \\
\hline \multicolumn{1}{c}{ Total } & 54 & 100.0 & 56 & 100.0 & 48 & 100.0 & 158 & 100.0 \\
\hline
\end{tabular}

* - number of fungi-infected aphids out of 60 collected

Four species of entomopathogenic fungi were identified in mummies collected from DKC 3421 YG plants in July 2009, while three species were found in those from cv. DKC 3420 and from cv. 'Bosman' (Table 3). In a few cases mixed infections were also found. As in the previous year the dominant species on all maize cultivars was $P$. neoaphidis, and this caused mortality ranging between $62.3 \%$ (cv. DKC 3420) and $77.1 \%$ (cv. DKC $3421 \mathrm{YG}$ ) of all the collected aphids. Less numerous were infections caused by C. thromboides. In the DKC 3420 , 'Bosman' and DKC 3421 YG cultivars 26.4\%, 25.9\% and $14.0 \%$ of the collected aphids were infected by this fungus, respectively. E. planchoniana was found infecting only single aphids on all cultivars that year. Neozygites fresenii was identified only from a single aphid, collected from $B t$ maize (cv. DKC 3421 YG). Mixed infections of $P$. neoaphidis and C. thromboides were observed only on DKC 3421 YG and DKC 3420 cultivars.

In October 2009, on all maize cultivars almost all of the collected aphids were infected by entomopathogenic fungi (Table 4). Three fungal species were observed, and mixed infections were identified in the insect material from each experimental treatment. In this period the dominant enthomopathogen was E. planchoniana. The highest mortality of aphids caused by this fungus was found on cv. DKC 3421 YG plants (57.9\%). On cv. 'Bosman' the aphid mortality reached $51.7 \%$, while on the cv. DKC 3420 it only amounted to $40.7 \%$. A high 
Table 3. Species composition of entomopathogenic fungi in 2009 (July)

\begin{tabular}{|c|c|c|c|c|c|c|c|c|}
\hline \multirow{2}{*}{ Species } & \multicolumn{2}{|c|}{ DKC3421 YG } & \multicolumn{2}{|c|}{ DKC 3420} & \multicolumn{2}{|c|}{ 'Bosman' } & \multicolumn{2}{|c|}{ Total } \\
\hline & $\mathrm{n}$ & $\%$ & $\mathrm{n}$ & $\%$ & $\mathrm{n}$ & $\%$ & $\mathrm{n}$ & $\%$ \\
\hline Pandora neoaphidis (Remaudiere et Hennebert) Humber & 44 & 77.2 & 33 & 62.3 & 37 & 68.5 & 114 & 69.5 \\
\hline Entomophthora planchoniana Cornu & 2 & 3.5 & 2 & 3.8 & 3 & 5.6 & 7 & 4.3 \\
\hline Conidiobolus thromboides Dreschler & 8 & 14.0 & 14 & 26.4 & 14 & 25.9 & 36 & 21.9 \\
\hline Neozygites fresenii (Nowakowski) Remaudiere et Keller & 1 & 1.8 & 0 & 0 & 0 & 0 & 1 & 0.6 \\
\hline Mixed infection C. thromboides $+P$. neoaphidis & 2 & 3.5 & 4 & 7.5 & 0 & 0 & 6 & 3.7 \\
\hline Total & 57 & 100.0 & 53 & 100.0 & 54 & 100.0 & 164 & 100.0 \\
\hline
\end{tabular}

percentage $(40.7 \%)$ of aphids on the isogenic non- $B t$ cultivar (DKC 3420) was infected by N.fresenii. Fewer aphids were infected by the same species on cv. 'Bosman' (25.9\%), and on Bt maize (17.5\%). P. neoaphidis and $C$. thromboides, which had occurred in greater numbers in samples collected in July 2009, caused only single

Table 4. Species composition of entomopathogenic fungi in 2009 (October)

\begin{tabular}{|c|c|c|c|c|c|c|c|c|}
\hline \multirow{2}{*}{ Species } & \multicolumn{2}{|c|}{ DKC3421 YG } & \multicolumn{2}{|c|}{ DKC 3420} & \multicolumn{2}{|c|}{ 'Bosman' } & \multicolumn{2}{|c|}{ Total } \\
\hline & $\mathrm{n}$ & $\%$ & $\mathrm{n}$ & $\%$ & $\mathrm{n}$ & $\%$ & $\mathrm{n}$ & $\%$ \\
\hline Pandora neoaphidis (Remaudiere et Hennebert) Humber & 1 & 1.8 & 1 & 1.7 & 0 & 0 & 2 & 1.1 \\
\hline Entomophthora planchoniana Cornu & 33 & 57.9 & 24 & 40.7 & 30 & 51.7 & 87 & 50.0 \\
\hline Conidiobolus thromboides Dreschler & 0 & 0 & 0 & 0 & 3 & 5.2 & 3 & 1.7 \\
\hline Neozygites fresenii (Nowakowski) Remaudiere et Keller & 10 & 17.5 & 24 & 40.7 & 15 & 25.9 & 49 & 28.2 \\
\hline Mixed infection E. planchoniana $+N$. fresenii & 13 & 22.8 & 10 & 16.9 & 10 & 17.2 & 33 & 19.0 \\
\hline Total & 57 & 100.0 & 59 & 100.0 & 58 & 100.0 & 174 & 100.0 \\
\hline
\end{tabular}

In July 2010, there were three (on cvs DKC 3421 YG and DKC 3420) or four (on cv. 'Bosman') species of entomopathogens identified in the mycosed aphids (Table 5). As in October of the previous year E. planchoniana was the most abundant on all cultivars. The level of infection caused by this species was very high, and it was similar on each cultivar, oscillating between $76.5 \%$ of aphids mycosed on cv. DKC 3421 YG, to $80.8 \%$ on cv. DKC 3420. The infections in October that year. Conversely, on all the observed cultivars mixed infections of E. planchoniana and $N$. fresenii were common in October. Mortality caused by these infections ranged from $16.9 \%$ (cv. DKC 3420 ) to $22.8 \%$ (cv. DKC $3421 \mathrm{YG}$ ).

Table 5. Species composition of entomopathogenic fungi in 2010 (July)

\begin{tabular}{|c|c|c|c|c|c|c|c|c|}
\hline \multirow{2}{*}{ Species } & \multicolumn{2}{|c|}{ DKC3421 YG } & \multicolumn{2}{|c|}{ DKC 3420} & \multicolumn{2}{|c|}{ 'Bosman' } & \multicolumn{2}{|c|}{ Total } \\
\hline & $\mathrm{n}$ & $\%$ & $\mathrm{n}$ & $\%$ & $\mathrm{n}$ & $\%$ & $\mathrm{n}$ & $\%$ \\
\hline Pandora neoaphidis (Remaudiere et Hennebert) Humber & 11 & 21.6 & 10 & 19.2 & 10 & 18.2 & 31 & 19.6 \\
\hline Entomophthora planchoniana Cornu & 39 & 76.5 & 42 & 80.8 & 43 & 78.2 & 124 & 78.5 \\
\hline Conidiobolus thromboides Dreschler & 0 & 0 & 0 & 0 & 1 & 1.8 & 1 & 0.6 \\
\hline Neozygites fresenii (Nowakowski) Remaudiere et Keller & 1 & 1.9 & 0 & 0 & 1 & 1.8 & 2 & 1.3 \\
\hline Total & 51 & 100.0 & 52 & 100.0 & 55 & 100.0 & 158 & 100.0 \\
\hline
\end{tabular}

\section{Discussion}

Pests in agroecosystems have a wide range of natural enemies, including predators, parasitoids and pathogens. Fungal entomopathogens are often used for classical biological control, but not very much is known about them when occurring naturally in agricultural habitats (Meyling, Hajek, 2010). The most widely recognized fungal pathogens that infect aphids come from the order of Entomophthorales. This order includes six species of fungi commonly recorded from pest and nonpestaphidsworldwide: Pandoraneoaphidis, Conidiobolus obscurus, Entomophthora planchoniana, Neozygites fresenii, Zoophthora phalloides and Z. radicans (Powell, Pell, 2007). Several Hypocreales (Ascomycota) genera, such as Beauveria, Verticillium and Paecilomyces, are also known to infect aphids (Milner, 1997). Four species of entomopathogenic fungi have already been identified from mycosed aphids collected from maize in Poland, and these are P. neoaphidis, C. thromboides, second important species, identified in samples collected in July was $P$. neoaphidis, causing likewise, mortality similar on all the cultivars, ranging from $18.2 \%$ on the $\mathrm{cv}$. 'Bosman' to $21.6 \%$ on the cv. DKC 3421 YG. Another two species: C. thromboides and $N$. fresenii, were also found in mycosed aphids, but only single aphids were infected by these species. Similar to 2008, in October 2010, no aphid mycoses were observed on maize. 
consumed the toxin. A large number of studies exploring risk assessments of GM maize with Cry1 $\mathrm{Ab}$ protein on different non-target organisms, whether predatory or parasitic, indicate no effect (Naranjo, 2009; Twardowski et al., 2012; 2014). Aphids feed predominantly on phloem sap (Douglas, 2003), but they also provide food for many beneficial organisms. It seems reasonable to consider the influence of $B t$ maize on entomopathogens through their aphid hosts. The vast majority of studies indicate no effect of such varieties on aphids. In most cases laboratory investigations concluded that aphids could not be affected because the toxin is not transported in the phloem sap on which these insects feed (Raps et al., 2001; Pons et al., 2005). However, there are also a few reports relating different GM plants, mentioned in introduction, pointing to the prospective, indirect action on these herbivores and their natural enemies (Lumbierres et al., 2004; Burgio et al., 2011; Stephens et al., 2012). Open field studies are crucial for the evaluation of potential side effects of GM crops, and outcomes on aphids could cascade up to higher trophic levels, thus affecting the whole food web. In our other trials, no effect of $B t$ maize on bird cherry-oat aphid population development was recorded (unpublished). Similar results were achieved by Eckert et al. (2006), and Ramirez-Romero et al. (2008). Also, Habuštova et al. (2014) showed in field studies that the infestation of aphids, mainly Rhopalosiphum padi and Metopolophium dirhodum, was similar in both $B t$ and non- $B t$ plots. Because of the reflections above, and according to the results of our trials, we assume no effect of $B t$ maize on entomopathogens recorded on cereal aphids colonizing maize in the GM ecosystem. In the review form Lundgren et al. (2009) stated that there is evidence for both positive and negative indirect effects of Cry toxin on entomopathogens. In the literature some effects of $B t$ toxins on fungi in soil were better examined. For example Saxena and Stotzky (2001) indicated that the toxin released in root exudates of $B t$ maize or from the degradation of biomass of this genetically modified plant is not toxic to fungi, as well as other soil organisms. Some synergistic interactions between Cry toxin and entomopathogen fungi have also been found (Wraight, Ramos, 2005). Taken this latter knowledge into account, Lundgren et al. (2009) pointed out that hypothesis about positive or negative effects of $B t$ plants on fungi should be validated by looking on specific entomopathogen species or community.

\section{Conclusions}

1. The number of aphids infected by entomopathogenic fungi and their time of occurrence in the course of the growth season were very similar on the conventional maize cultivar 'Bosman', on the DKC 3421 Yield Gard Bt, and their isogenic line DKC 3420. No statistical differences between cultivars were found.

2. The same three or four entomopathogenic fungi-infected aphids were identified on the conventional maize, as well as on the transgenic $B t$ and on the isogenic non-Bt maize cultivars. Pandora neoaphidis (Remaudiere et Hennebert) Humber was the most abundant species in July of 2008 and 2009. Entomophthora planchoniana Cornu predominated in the enthomopathogens assemblage in October 2009 and in July 2010.

3 . In the three years of the study no influence of the $B t$ maize on the number, quantity changes of fungi- infected aphids, or on the spectrum of fungal species was found.

\section{Acknowledgements}

This subproject entitled "Impact of MON 810 maize on non-target arthropod species and trophic interactions under the Polish environmental conditions" was implemented in the framework of project "Environmental and economic aspects of permitting cultivation of GM crops in Poland" funded by Polish Ministry of Science and Higher Education.

Received 31082013

Accepted 26012014

\section{References}

Bereś P. K. 2010. Harmfulness of Ostrinia nubilialis Hbn. on some non-Bt versus genetically modified $B t$ maize (Zea mays L.) cultivars in Poland in 2006-2007. Journal of Plant Protection Research. 50 (1): 110-116 http://dx.doi.org/10.2478/v10045-010-0019-Z

Burgio G., Dinelli G., Marotti I., Zurla M., Bosi S., Lanzoni A. 2011. Bt-toxin uptake by the non-target herbivore, Myzus persicae (Hemiptera: Aphididae), feeding on transgenic oilseed rape in laboratory conditions. Bulletin of Entomological Research. 101 (2): 241-247 http://dx.doi.org/10.1017/S0007485310000441

Chen C., Feng M. G. 2005. Epizootiological modeling of Pandora neoaphidis mycosis transmission in Myzus persicae colonies initiated by primarily infected alates. Applied and Environmental Microbiologv. 71: 4104-4107 http://dx.doi.org/10.1128/AEM.71.7.4104-4107.2005

Douglas A. E. 2003. The nutritional physiology of aphids. Advance in Insect Physiology, 31: 73-140 http://dx.doi.org/10.1016/S0065-2806(03)31002-1

Dutton A., Klein H., Romeis J., Bigler F. 2002. Uptake of $B t$-toxin by herbivores feeding on transgenic maize and consequence for the predator Chrysoperla carnea. Ecological Entomology, 27: 441-447 $\mathrm{http}: / / \mathrm{dx}$.doi.org/10.1046/j.1365-2311.2002.00436.x

Eckert J., Schuphan I., Hothorn L. A., Gathmann A. 2006. Arthropods on maize ears for detecting impacts of Bt maize on non target organisms. Environmental Entomology, 35 (2): $554-560$ http://dx.doi.org/10.1603/0046-225X-35.2.554

Ekesi S., Shah P. A., Clark S. J., Pell J. K. 2005. Conservation biological control with the fungal pathogen Pandora neoaphidis: implications of aphid species, host plant and predator foraging. Agricultural and Forest Entomology, 7: $21-30$ http://dx.doi.org/10.1111/j.1461-9555.2005.00239.x

Faria C. A., Wäckers F. L., Pritchard J., Barret D. A., Turlings T. C. J. 2007. High susceptibility of Bt maize to aphids enhances the performance of parasitoids of lepidopteran pests. PLoS ONE. 2 (7): e600 http://dx.doi.org/10.1371/journal.pone.0000600

Habuštova O., Doležal P., Spitzer L., Svobodová Z., Hussein H., Sehnal F. 2014. Impact of CrylAb toxin expression on the non-target insects dwelling on maize plants. Journal of Applied Entomology, 138 (3): 164-172 http://dx.doi.org/10.1111/jen.12004

Honek A. 1994. The effect of plant quality on the abundance of Metopolophium dirhodum (Homoptera: Aphididae) on maize. European Journal of Entomology, 91 (2): 227-236

Humber R. A. 1997. Fungi: identification. Lacey L. A. (ed.). Manual of techniques in insect pathology. London, UK, p. $153-185$

Keller S. 1987. Arthropod-pathogenic Entomophthorales of Switzerland. I. Conidiobolus, Entomophaga and Entomophthora. Sydowia, 40: 122-167

Keller S. 1991. Arthropod-pathogenic Entomophthorales of Switzerland. II. Erynia, Eryniopsis, Neozygites, Zoophthora and Tarichium. Sydowia, 43 (1): 39-122 
KrawczykA.,MiętkiewskiR.,HurejM.2006.Enthomopatogenic fungi infected aphids feeding on corn. Progress in Plant Protection, 46 (2): 378-381 (in Polish)

Lövei G. L., Arpaia S. 2005. The impact of transgenic plants on natural enemies: a critical review of laboratory studies. Entomologia Exnerimentalis et Annlicata. 114 (1): 1-14 http://dx.doi.org/10.1111/j.0013-8703.2005.00235.x

Lumbierres B., Albajes R., Pons X. 2004. Transgenic Bt maize and Rhopalosiphum padi (Hom., Aphididae) performance. Ecological Entomology, 29: 309-317 http://dx.doi.org/10.1111/j.0307-6946.2004.00597.x

Lundgren J. G., Gassman A. J., Bernal J., Duan J. J., Ruberson J. 2009. Ecological compatibility of GM crops and biological control. Crop Protection. 28: 1017-1030 http://dx.doi.org/10.1016/j.cropro.2009.06.001

Meyling N. V., Hajek A. E. 2010. Principles from community and metapopulation ecology: application to fungal entomopathogens. Biocontrol, 55: 39-54 $\mathrm{http}: / / \mathrm{dx}$. doi.org/10.1007/s10526-009-9246-5

Milner R. J. 1997. Prospects for biopesticides for aphid control. Entomonhaga. 42: 227-239 http://dx.doi.org/10.1007/BF02769900

Naranjo S. E. 2009. Impacts of $B t$ crops on non-target invertebrates and insecticide use patterns. CAB Reviews: Perspective in Agriculture, Veterinary Science, Nutrition and Natural Resources. 4: 1-23 http://dx.doi.org/10.1079/PAVSNNR20094011

O'Callaghan M., Glare T. R., Burgess E. P. J., Malone L. A. 2005. Effects of plants genetically modified for insect resistance on nontarget organisms. Annual Review Entomology. 50: 271-292 http://dx.doi.org/10.1146/annurev.ento.50.071803.130352

Pieńkosz A., Leszczyński B., Warzecha R. 2005. Susceptibility of corn towards cereal aphids. Progress in Plant Protection, 45 (2): 989-992 (in Polish)

Pons X., Lumbierres B., Lopez C., Albajes R. 2005. Abundance of non-target pests in transgenic Bt-maize: a farm scale study. Euronean Journal of Entomology, 102: 73-79 http://dx.doi.org/10.14411/eje.2005.010

Powell W., Pell J. K. 2007. Biological control. Van Emden H. F., Harrington R. (eds). Aphids as crop pests. Wallingford, UK, p. 469-514
Ramirez-Romero R., Desneux N., Chaufaux J., Kaiser L. 2008. Bt-maize effects on biological parameters of the non-target aphid Sitobion avenae (Homoptera: Aphididae) and Cryl $\mathrm{Ab}$ toxin detection. Pesticide Biochemistry and Physiology, 91: 110-115 http://dx.doi.org/10.1016/j.pestbp.2008.01.010

Raps A., Kehr J., Gugerli P., Moar W. J., Bigler F., Hilbeck A. 2001. Immunological analysis of phloem sap of Bacillus thuringiensis corn and of the nontarget herbivore Rhopalosiphum padi (Homoptera: Aphididae) for the presence of Cry1Ab. Molecular Ecology, 10: 525-533 http://dx.doi.org/10.1046/j.1365-294x.2001.01236.x

Saxena D., Stotzky G. 2001. Bacillus thuringiensis $(B t)$ toxin released from root exudates and biomass of $B t$ corn has no apparent effect on earthworms, nematodes, protozoa, bacteria, and fungi in soil. Soil Biology and Biochemistry, 33: $1225-1230$ http://dx.doi.org/10.1016/S0038-0717(01)00027-X

Stephens E. J., Losey J. E., Allee L. L., Ditommaso A., Bodner C., Breyre A. 2012. The impact of Cry3Bb Btmaize on two guilds of beneficial beetles. Agriculture, Ecosystems and Environment. 156: 72-81 $\mathrm{http} / / / \mathrm{dx}$.doi.org/10.1016/j.agee.2012.05.002

Twardowski J. P., Bereś P. K., Hurej M., Klukowski Z., Dąbrowski Z., Sowa S., Warzecha R. 2012. The quantitative changes of ground beetles (Col., Carabidae) in Bt and conventional maize crop in South Poland. Journal of Plant Protection Research, 52 (4): 404-409 http://dx.doi.org/10.2478/v10045-012-0066-8

Twardowski J., Bereś P., Hurej M., Klukowski Z. 2014. A quantitative assessment of the unintended effects of Bt-maize (MON 810) on rove beetles (Col., Staphylinidae) assemblages. Polish Journal of Environmental Studies, 23 (1): $215-220$

Wraight S. P., Ramos M. E. 2005. Synergistic interaction between Beauveria bassiana and Bacillus thuringiensis tenebrionis-based biopesticides applied against field populations of Colorado potato beetle larvae. Journal of Invertebrate Pathologv. 90 (3): 139-150 http://dx.doi.org/10.1016/j.jip.2005.09.005

ISSN 1392-3196 / e-ISSN 2335-8947

Zemdirbyste-Agriculture, vol. 101, No. 3 (2014), p. 279-284

DOI $10.13080 /$ z-a.2014.101.036

\title{
Insekticidinio baltymo Cry1 AB įtaka entomopatogeninių grybų, infekuojančių amarus ant $B t$ kukurūzų, paplitimui
}

\author{
M. Hurej ${ }^{1}$, R. Miętkiewski², J. P. Twardowski ${ }^{1}$ \\ ${ }^{1}$ Vroclavo aplinkos ir gyvybès mokslų universitetas, Lenkija \\ ${ }^{2}$ Podlasie universitetas, Lenkija
}

\begin{abstract}
Santrauka
Europoje transgeniniai kukurūzai yra vertinami nevienareikšmiškai. Tyrimų tikslas - nustatyti kiekybinius grybais infekuotu amarų santykio pokyčius ir galimus entomopatogeninių grybų rūšinès sudetties skirtumus ant tradicinių ir genetiškai modifikuotų kukurūzų, ekspresuojančių Cry1 Ab baltymą iš Bacillus thuringiensis (Bt). Tyrimai atlikti 20082010 m. Žemutineje Silezijoje, Lenkijoje. Tirtos trys kukurūzų veislès: DKC 3421 YG $(B t)$, izogenine (ne $B t$ ) DKC 3420 ir tradicinè ‘Bosman' (kontrolinè). Vegetacijos sezonų metu kas dvi savaitès ant 18 augalų laukelyje in situ buvo suskaičiuoti užsikrètę grybais amarai. Papildomai du kartus per metus buvo renkami negyvi amarai (60 amarų iš kiekvieno varianto), kurie naudoti grybams identifikuoti. Insekticidinis baltymas Cry1 AB entomopatogeninių grybų, infekuojančių amarus ant $B t$ kukurūzų, paplitimui neturejjo įtakos. Grybais užsikrètusių amarų kiekis ir jų pasirodymo laikas ant visų trijų tirtų veislių augalų buvo panašus. Tos pačios trys arba keturios entomopatogeniniais grybais užsikrètusių amarų rūšys buvo nustatytos kiekviename variante. Visuose variantuose vyravo Pandora neoaphidis, Entomophthora planchoniana ir Conidiobolus thromboides.
\end{abstract}

Reikšminiai žodžiai: Cry1 Ab baltymas, genetiškai modifikuoti augalai, grybais infekuoti amarai, kenkejas, transgeniniai kukurūzai. 